\title{
Uma heroína chamada Rute: análise narrativa e intertextual de R† 3
}

Orientador: Leonardo Agostini Fernandes

Doutoranda: Alessandra Serra Viegas

Área de Concentração: Teologia Bíblica

Linha de Pesquisa: Análise e Interpretação de Textos do Antigo e Novo Testamento

Projeto de Pesquisa: Bíblia e Teologia: relações, metodologias e interdisciplinaridade entre exegese, teologia, fé e praxe pastoral

Rute é uma mulher pobre, viúva e estrangeira moabita. Não obstante isso, é uma mulher de força/valor, em atitudes e palavras; é uma mulher decidida que se comporta em termos de paridade com Booz, o homem que ao seu lado divide a cena central em Rt 3: a cena da eira. A presente tese, intitulada Uma heroína chamada Rute: análise narrativa e intertextual de Rt 3, buscou mostrar, por meio da exegese narrativa, as possibilidades que assinalam essa paridade entre os protagonistas, Rute e Booz, através da análise de seus atos e falas, quer pelo tratamento que o autor, através da voz do narrador dá a cada um, quer pelo discurso destes personagens, valorizando, ainda, a importância e o papel de Noemi nas cenas anterior e posterior à cena da eira. A seguir, a partir da análise intertextual bíblica e extrabíblica, foi possível identificar outras mulheres que em muito se assemelham à pessoa, às características e ao comportamento de paridade entre Rute e Booz em Rt 3: as mulheres bíblicas Débora, Jael, Abigail e a mulher de Pr 31,10-31, bem como as mulheres extrabíbicas Arete e Alceste, todas com seus pares masculinos em cena. Esta aproximação permitiu aplicar a Rute o conceito de heroína, conforme o modelo literário dos textos da Antiguidade. Nestes, mulheres fortes, corajosas e pares dos homens caracterizam as heroínas, seja nos textos que retratavam a sociedade em Israel, no Antigo Oriente Próximo, ou entre os povos da Grécia continental e insular, os quais circulavam na bacia do Mediterrâneo.

Palavras-chave: Rute. Heroína. Exegese. 